\title{
A Systematic Review on Radiologists' Knowledge of Breast Cancer Screening
} 영상의학과 의사들을 위한 유방암 검진의 이해

\section{Sung Hun Kim, MD*}

Department of Radiology, Seoul St. Mary's Hospital, College of Medicine, The Catholic University of Korea, Seoul, Korea

This is an Open Access article distributed under the terms of the Creative Commons Attribution Non-Commercial License (https://creativecommons.org/ licenses/by-nc/4.0) which permits unrestricted non-commercial use, distribution, and reproduction in any medium, provided the original work is properly cited.

\section{ORCID iD}

Sung Hun Kim (D)

https://

orcid.org/0000-0003-4478-9720

https://doi.org/10.3348/jksr.2019.80.1.8

J Korean Soc Radiol. 2019 Jan;80(1):8-18

The publisher and authors would like to draw the reader's attention to an error in the following article: A Systematic Review on Radiologists' Knowledge of Breast Cancer Screening

On page 8, There was an error in the title. We have revised "A Systematic Review on Radiologists' Knowledge of Breast Cancer Screening" to "Understanding Breast Cancer Screening for Radiologists.” 